\title{
Poor women empowerment service through microfinance Grameen bank system (case study of Mitra Dhuafa Cooperative /Komida)
}

\author{
Slamet Riyadi ${ }^{1}$ \\ Sulaeman Rahman Nidar ${ }^{2} *$ \\ ${ }^{1}$ Student of Integrated Microfinance Management, Padjadjaran University \\ ${ }^{2}$ Lecturer of Management and Business Department, Padjadjaran University \\ *Corresponding author: sulaeman.rahman@unpad.ac.id
}

\begin{abstract}
Poverty is a complex problem that is faced by all governments in the world. It was influenced by several factors that are interrelated with each other. These factors include the level of income, education, health, access to goods and services, geographic location, gender and environmental conditions. Strategic effort to do in order to empower SMEs include: First, Creating a climate conducive to the development of SMEs include the regulation and protection of business, creating a system of guarantees for micro businesses and provide technical assistance in the form of mentoring and managerial assistance. Second, Enlarge the access of credit to financial institutions included in this is access to finance to microfinance institutions, that is one of Microfinance Grameen Bank system. With these two steps, then the SME sector will be more actives that will ultimately result in the reduction of poverty. This article will present the experience of Microfinance Grameen Bank system "Koperasi Mitra Dhuafa or Komida" who have committed financial services to poor women since 2005 . From over 10 years experience to serve and assist poor families, some changes occurred including increases income, access to health and improving the quality of education.
\end{abstract}

Keywords: Poor Women, SME, Microfinance, Grameen Bank System

\section{INTRODUCTION}

One of the barriers to economic development is poverty. It is the benchmark for a country whether ongoing construction can be enjoyed by all citizens regardless of things that are attributive. In other words, the construction of which took place actually distributed in society.

Poverty is not something that stands alone, because it is the result of not achieving lasting economic development. In this case, poverty will be on the increase as the absence of equitable development. In 2005 the number of poor people reached 35.1 million people (15.97 percent) and increased to 39.05 million (17.75 per cent) in 2006. Between 2005 to 2006 the number of poor people increased by 3.95 million (BPS 2010).

In 2007 the estimated number of poor people is still quite large compared to the number before the year 2006. Meanwhile, in the National Medium Term Development Plan (RPJMN) 2004-2009 The government already has targeted reducing the number of poor people in 2009 to reach 8.2 percent. Thus, the Government requires a huge effort to achieve these goals. Therefore, in 2008 the government will seek to increase the effectiveness of poverty reduction.

In principle, the approach taken to solve the problems of poverty must be multidimensional 
considering the causes of poverty is not only a physical problem but it also relates to issues of economic, social, and cultural. The existence of SME sector that has been neglected by the government can be said to be characterized by a lack of policies in favor of this sector, today increasingly taken root how the SME sector is vital to sustain the life of the Indonesian economy. It is the mark with the existence SME sector when the monetary crisis hit Indonesia in 1997 when compared with other sectors.

Development of the SME sector has been quite encouraging. Enhancing the role of the SME sector and business activities are now evident, especially since the crisis in 1997 . In the midst of the process of restructuring the corporate sector and state-owned enterprises is slow, the SME sector has shown increasing growth and even capable of being sustaining national economic growth. Meanwhile, progress in the restructuring in the financial sector, especially the banking industry, has also been able to provide the financing needs of growth rates and larger portions for SMEs. The development is the primary driving force for growth and the role of SME sector in the national economy.

However, the SME sector with its vital role as the backbone of Indonesian economy instrument which also have an impact on poverty reduction is still faced with some problems such as lack of access granted by the government through financial institutions and regulatory policies in favor of this sector. Nevertheless, we should be optimistic about the progress of SME sector as a competitive instrument of poverty reduction.

During the New Order is still in power, have issued many policies poverty. Moelyarto (1993) grouping policies and poverty reduction programs into several types as follows:

1. The transfer development resources from the center to the regions in the form of Presidential Decree;

2. Improved access of the poor to different forms of Presidential Decree;
3. Expansion of the range of credit institutions for small people (Kupedes, KURK, BKK, KCK, Credit Guidance, etc.);

4. The infrastructure development of rural economy, particularly the agricultural infrastructure;

5. Institutional development in areas related to poverty alleviation, such as program development of small farmers' income (P4KT) and so on.

6. In addition, there is also a poverty reduction program Improvement (KDP) which is phenomenal that became known by the name Presidential Decree for Villages (IDT) and the Family Welfare Program (by Presidential Decree No. 3 of 1996) (Sarman and Sajogja, 2000).

Small and Microfinance Services The Indonesian economy shattered as the impact of the economic crisis of 1997 provide valuable lessons for many parties of the importance of small micro enterprises as one of the saviors of the national economy. So far, the government relied on large-scale business sector and conglomerates as the locomotive of development turned out to be highly resistant to the crisis shaking. Small and Medium Enterprises (SMEs) turned out to appear as a sector that is still able to drive the economy in times of large businesses and conglomerates busy escape from the entanglement of debt and bankruptcy. SMEs play an important role in the economy and become the foundation of life for the community. One piece of evidence was showing that the important role of SME is an unusually large population. Based on data from the Central Bureau Statistics 2000, SME in Indonesia reached 99.9 per cent of the existing economic actors. Of the 39 million enterprises in Indonesia, the Central Bureau Statistics (BPS) said that 2,005 of them are large enterprises, 55,437 are medium-sized businesses, and 39.12135 million small businesses (with 90 percent of them are micro enterprises) (BPS, Profile SMEs without Legal Entity, 2000 Jakarta in Retnadi 2003). SME great potential is to 
realize many parties to formulate a model for empowerment. These empowerment efforts in intended to reinforce the importance of SMEs for the role, which although quite large in number, but each SME is always faced with various problems.

Some approaches, such as assistance in the management, promotion and marketing, technical capacity and production technology, widely used to empower the MSE. The provision of microfinance services is one of the models approach used in an effort to empower SME, and much talked about, especially in the period of last 10 years. Microfinance institution is the institution conducting the provision of financial services to micro and small entrepreneurs and low-income people who are not served by formal financial institutions and which have been market-oriented for business purposes. According to the Asian Development Bank and the World Bank, there are three key elements of microfinance institutions, which provides a variety of financial services to the real needs of the community served, serve groups of low-income people, as well as the procedures and mechanisms are contextual and flexible to make it more easily accessible to the public the poor who need the service. Movers' microfinance institutions can come from the banking and non-banking sectors such as NGOs, non-governmental organizations, as well as cooperation between local governments and banks. In society itself has evolved mechanisms of financial services that benefit the poor, such as rotating savings and credit association (ROSCAs), gathering, pawn shops, and bankfinancial services daily managed as benefits a bank by individuals. Institutions and mechanisms of financial services is not always efficient and be a nice option for the poor. But its presence indicates that the financial needs of the poor are already quite developed in many variations, from the individual to the group, from the very friendly and empathy for the difficulties of the poor to exploitative of the poor people. A new approach to microfinance programs that include credit services, savings and loans, and savings that began piloted in 1994 in six pilot project countries. Those countries include Bolivia, Guatemala, Kenya, Mali, Nepal, and the Philippines. The new approach is then applied in many other countries. The new microfinance program is intended to build financial institutions that can run continuously as well as independent, selffinancing operations of the revenues they receive. The microfinance services intended for poor women who are used to develop productive activities that can increase family income and welfare of children in turn. In addition it is expected to boost their economy class through microfinance services and activities of other income-generating. Komida as microfinance institutions concern to microfinance services to poor women is also implementing the principles of microfinance. The general objective of microfinance Komida program is as follows;

1. The increase in family income would at the same time improving the welfare of children.

2. The program is intended for poor women is one of the most effective ways to improve access and efficient family health.

3. Attributes credit and savings with other domains will also increase the overall investment in children's education and the environment.

Economic activity undertaken by poor women who obtain microfinance services is expected to provide a wide range of positive impacts. Based on the concept AIMS Conceptual Framework (Sebtad, et.al., 1999), the impact is measured from the level of families, small businesses are run, the individual level, the community level, social networks, and social participation. Until now many people have been involved in the provision of microfinance services, both the government sector, donor agencies, NGOs and lately private institutions, such as cooperatives and banks. Development of various service providers of microfinance is then also affect the discourse of microfinance services. The key to 
successful microfinance services not only in terms of outreach to the poor and her contribution to the alleviation of poverty, but also continuity (sustainability) relevant institutions in the implementation of microfinance services. In practice it is difficult to integrate and successfully realize both indicators simultaneously. It often happens that the achievement indicators, in terms of overcoming poverty for example, was not followed by the achievement of the second indicator, and vice versa. This is due to financial services for poor people is costly, while for achieving sustainability requires institutional efficiency. The provision of microfinance services has distinctive features as well as a simple procedure, no full and fast rule is the key of this micro finance institutions. This is what the last 10 years carried out by Komida.

\section{METHODS}

The method used in this research is descriptive qualitative. Researchers conducted the study by collecting data from Komida, both primary and secondary. Analyses were performed using the theory of microfinance and cooperatives, as well as SME theory.

\section{RESULTS AND DISCUSSION}

\section{a. Koperasi Mitra Dhuafa (Komida).}

One form of microfinance institutions is a model of Grameen Bank. Grameen Bank is a poverty reduction strategy that was first introduced in Bangladesh. Grameen itself in Bengali means village or commune. Literally Grameen Bank means the bank earmarked for the villagers who also can mean poor people. Grameen Bank targets are indeed poor people who do not have access to loans from conventional banks or other commercial financial institutions. More specifically Grameen Bank prioritizes women as a target group lending. Women represent marginalized groups in poor communities. Poor women are regarded as an effective target for additional revenue earned women proved capable of improving the lives of the household, including the health and welfare of children. In addition a number of studies have shown that women have less credit risk than male group, and have the responsibility to manage limited resources. One of microfinance institutions in Indonesia using the Grameen Bank system is Dhuafa Cooperative Partners (Komida). Komida established in 2005 initially to help victims of the tsunami and the earthquake victims in Jogyakarta. Objectives and specific targets microfinance with Grameen Bank method implemented by Komida are:

Service Grameen Bank microfinance model implemented by Komida, but aims to help poor people, especially women to further increase its capacity, this model is supported by the scheme of service siding and empathy for the poor because it is made very simple so easily accessible. Schemes such services include:

1. The loans granted to individuals, as a group (consisting of 5 persons)

\section{There should be no collateral and guarantors}

3. There should be no legal sanctions, if not restore

4. No need to come to the office (bank) to obtain a loan, the officer who came to the members in group meetings

5. The procedure is made simple, no form which is not understood by the members

6. There is a compulsory savings are of little value to familiarize poor women save.

The specific objectives of the institution Grameen Bank replication performed by Komida is to improve access and services to capital for poor women through the container / financial institutions which will be jointly owned by Grameen Bank replication system that is named Koperasi Mitra Dhuafa (Komida). The type of activities undertaken, among others:

1. Providing capital assistance (loans) with the Grameen Bank system 
2. Provide assistance in enhancing the efforts of the resources (illiterate become literate, etc.)

3. Provide training both for the group and to the chairman of deliberation, such as motivational training groups, training environmental health, gender training, reproductive health training, group training and bookkeeping.

Goal of the program is Komida poorest people (especially women) in a certain area, which is based on existing standards in Komida, covering home index, per capita income, etc. How to capture the target through surveys, public meetings, feasibility and training of prospective members (Grameen standard). Criteria goal is the poorest women with the following criteria:

- Condition of the modest home, the size of small houses, the walls of the house up to the wall, the maximum index of 15 ,

- Index a maximum income of US \$2, - per day per capita.

- Index productive assets maximum Rp1 million

- Have activities that enable to earn revenue.

Komida development up to 2016 per month of July are as presented in Table 1:

\section{Table 1. Komida development}

\section{b. Impact On Welfare Program}

Since its establishment, Komida already preparing indicator to determine the impact of microfinance programs to its members. It is for Komida very important because as a financial institution specialized services to poor women, the impact of the members must be known for sure. Measurement of impact against a member or customer is almost never been done by a financial institution in Indonesia. One of the tools used by Komida is PPI form or progress out of poverty indext. In the PPI form contained 10 questions taken from BPS. PPI data taken before members get a loan and every loan will be paid back PPI data collection. From the available data, each year Komida analyzing the changes of its members. Of the PPI data were collected and analyzed will be known among others

1. What percentage of children of school age members (5-17 years) can access to education.

2. What percentage of members who can Komida crossed the poverty line of US \$ 1, US \$ 1.5 and US \$ 2 .

3. What percentage Komida members can access clean water and sanitation

4. How much is the increase in member savings.

5. Etc.

Here is the impact of microfinance programs implemented Komida from 2005 until 2015.

\section{A. Increased Revenue.}

One objective of microfinance programs implemented Komida is increasing the family income. To measure changes in the members' income, Komida using PPI data (progress out of poverty index) and the Feasibility test data that includes data index home, index assets and income. From the analysis of this data can be seen that the first and second loan had not affected the revenue and new change occurred after the loan to three and so on.

\section{Figure 1. Percentage changes in poverty}

From Figure 1, it is seen that the first loan and the second, $70 \%$ of members Komida still below the poverty line of US $\$ 2.5$ per day. But in loans to seven and eight the number of members Komida are below the poverty line fell to $65 \%$. Keep in mind the time needed to get a member of the first loans up to 7 average of 5 years. So for 5 years member Komida poverty level fell by around 5\%.

\section{B. Improved Access to health.}

One of the objectives of microfinance as Komida is improving health access better. To increase access to these health Komida activities 
undertaken include the motivation to members at the meeting center meeting every week. It also conducted training is conducted in a structured health by the Community Development team Komida. To support this, Komida also made financing for access to clean water and sanitation in order to better the quality of health members. Changes that occur in Komida can be seen from the following Figure 2.

\section{Figure 2. Changes in access to health care}

From figure 2 , it can be seen any change in access to health facilities are better member Komida of only $6 \%$ increase to $26 \%$. So there was an increase of nearly $20 \%$.

\section{Improving the quality of education}

Interest microfinance program conducted by Komida is increased access to education of children of members. Since the start of 2005, only at the end of 2015 all members of schoolage children (ages 5-17 years) have access to education. Even more interesting is the desire of members to send their children to college and university level is high at almost $52 \%$. This is very important because until the end of 2015 on average almost children of members of the highest education until high school or vocational school.

\section{Figure 3. Motivation Member for his higher education}

\section{CONCLUSION}

From experience Komida implementing a microfinance program for poor women then there are some conclusions we can make, among other things:

a. Micro-finance programs designed specifically to serve poor women could walk with sustainable without government subsidies. b. Microfinance program specifically for poor women can help poverty reduction though not as quickly.

c. Microfinance programs should not only pursue quality and huge profits, but also must be concerned with the development of its members, namely the increase in income, health and education.

d. Poor people turned out to have a high sense of responsibility to repay the loan and Komida already proved with microfinance program for poor women without collateral and complex procedures return rate of nearly $100 \%$.

\section{REFERENCES}

Milford Bateman , 2010, “Why Doesn't Microfinance Work " , , Zed Books LTD, London

Chen, M., Sebtad, M., and O Cornel, L., 1999, Counting The Visible Workforce: The Case of Home Based Worker, World Bank, India.

Soetanto H, D. Retnadi, 2007, Empowering Microcredit as a solution to Overcome Unemployment and Poverty in Indonesia.

Muhtar Sarman, Sajogyo, 2000 , Masalah Penanggulangan Kemiskinan.Puspa Swara, Jakarta

Mulyarto Tjokrowinoto, 1993, Kemiskinan dan Kebijakan Pembangunan, Pustaka Pelajar, Indonesia.

http:// bmt-link.co.id/ Strategi-pengentasankemiskinan/ 5-5-2011

http://kjksibumandiri.multyply.com/journal/i tem/1 
Table 1. Komida development

\begin{tabular}{|l|l|l|}
\hline No & Description & Total \\
\hline 1 & $\begin{array}{l}\text { Number of } \\
\text { Members }\end{array}$ & 306.835 \\
\hline 2 & $\begin{array}{l}\text { Number of Branch } \\
\text { Offices }\end{array}$ & 134 \\
\hline 3 & Number of Province & 10 \\
\hline 4 & Total Outstanding & $\begin{array}{l}\mathrm{Rp} \\
411.675 .869 .000\end{array}$ \\
\hline 5 & $\begin{array}{l}\text { Portfolio at } \\
\text { Risk/PAR/NPL }\end{array}$ & $0,22 \%$ \\
\hline
\end{tabular}

Figure 1. Percentage changes in poverty

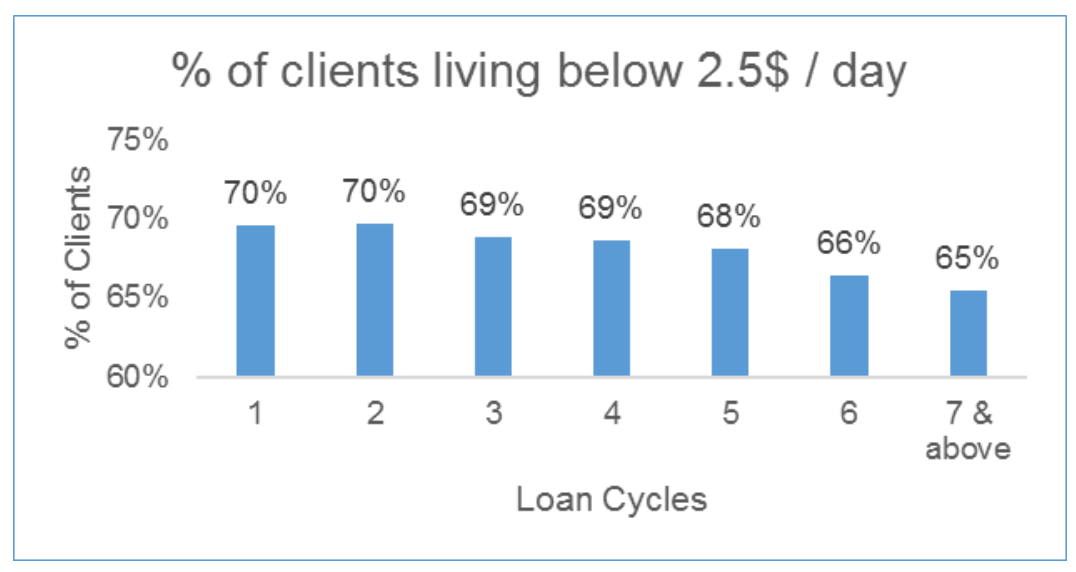


Figure 2. Changes in access to health care

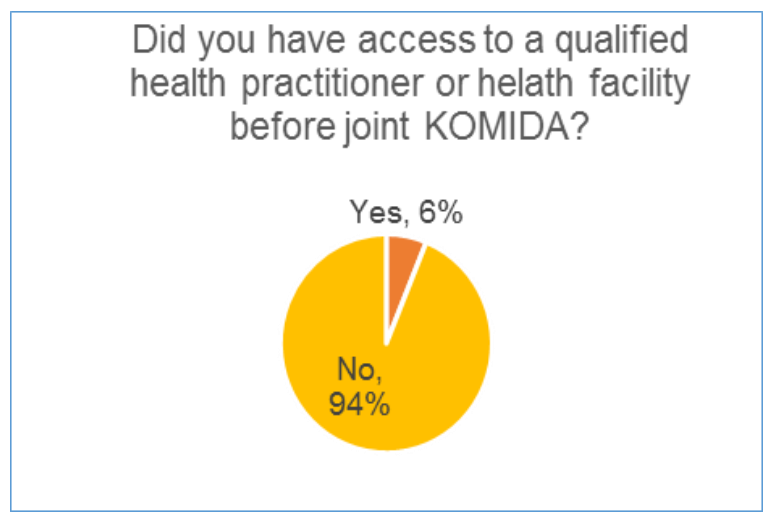

Did you have access to a qualified health practitioner or health facility for treatment after joint KOMIDA?

\section{Figure 3. Motivation Member for his higher education}

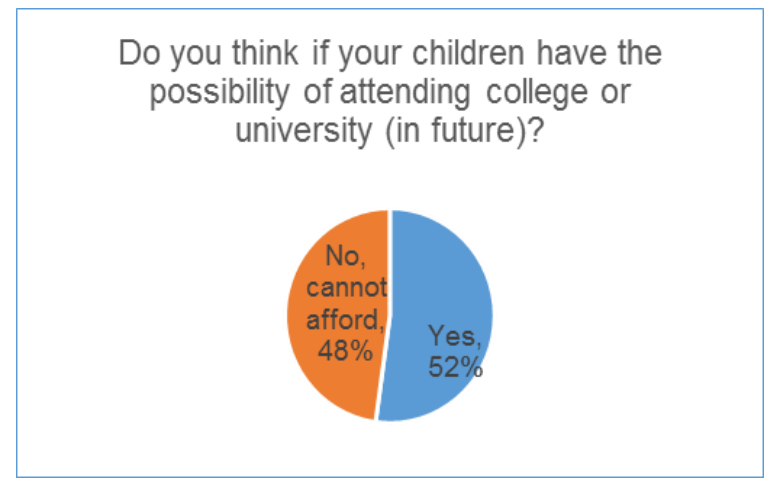

